GABA-GABA: Jurnal Pengabdian Masyarakat

dalam bidang Pendidikan Bahasa dan Seni

Vol. 1 No. 2, November 2021, Hal 82-87

e-ISSN : 2797-8494

\title{
PELATIHAN SISTEM DEBAT BAHASA INGGRIS BAGI GURU BAHASA INGGRIS SMA/SMK SE-KABUPATEN SERAM BAGIAN BARAT
}

\author{
Rosina Fransisca. J. Lekawael ${ }^{1)}$, Monica ${ }^{2)}$, Salmon James Hukom ${ }^{3)}$ \\ ${ }^{1}$ Program Studi Pendidikan Bahasa Inggris, FKIP Universitas Pattimura \\ email: rosina.lekawael@gmail.com \\ ${ }^{2}$ Program Studi Pendidikan Bahasa Inggris, FKIP Universitas Pattimura \\ email: monica.amboina@gmail.com \\ ${ }^{3}$ Program Studi Pendidikan Bahasa Inggris, FKIP Universitas Pattimura \\ Email: sjhukom@yahoo.com
}

\begin{abstract}
Abstrak
Debat Bahasa Inggris merupakan salah satu metode pembelajaran yang penting dan menjadi bagian dari kebutuhan sekolah dalam meningkatkan sumber daya manusia teristimewa ketrampilan komunikasi global. Untuk menjawab kebutuhan sekolah, pelatihan ini diinisiasi dan dilakukan oleh tim pengabdian dari Program Studi Pendidikan Bahasa Inggris, Fakultas Keguruan dan Ilmu Pendidikan, Universitas Pattimura. Peserta pelatihan yakni para guru Bahasa Inggris SMA/SMK se-kabupaten Seram Bagian Barat, Provinsi Maluku. Tujuan pelatihan ini untuk memberikan pemahaman yang komprehensif mengenai pentingnya kegiatan debat Bahasa Inggris melalui paparan sistem debat pada kompetisi debat Bahasa Inggris tingkat SMA/SMK secara lokal, regional, nasional maupun internasional. Pemahaman ini untuk ditandaklanjuti di sekolah dalam meningkatkan kemampuan keahlian berbicara dan berpikir kritis analitik bagi siswa dan guru sebagai pengajar sekaligus berpotensi membina dan melatih siswa untuk kemampuan dimaksud. Metode pelaksanaan dalam pelatihan ini meliputi tahapan persiapan, pembekalan dan keberlanjutan kegiatan. Pelaksanaan kegiatan dilakukan secara daring melalui aplikasi zoom dalam bentuk pemaparan pemahaman secara teoritis untuk selanjutnya tahapan keberlanjutan kegiatan dalam pendampingan dan pelatihan langsung secara luring kepada para guru. Hasil dari pelatihan ini yakni para guru memiliki pengetahuan yang mendalam mengenai debat Bahasa Inggris dan rekomendasi untuk pelatihan penguatan secara luring kepada para guru Bahasa Inggris sekolah tingkat SMA/SMK se-Kabupaten Seram Bagian Barat.
\end{abstract}

Kata Kunci: Pelatihan Sistem Debat Bahasa Inggris, Guru Sekolah Tingkat SMA/SMK

\begin{abstract}
English debate is one of the most important learning methods in senior high schools to improve global communication skills for both students and teachers. This English debate system training was initiated and carried out by the community service team of English Education Study Program, Teacher Training and Educational Sciences Faculty of Pattimura University. The target is English teachers at the SMA/SMK level in the western part of Seram Regency, Maluku Province. This training aims to provide comprehensive knowledge regarding the importance of English language debate activities to enhance students and teachers' critical and analytical thinking through the presentation of the debate system used in English language debate competitions at the SMA/SMK level, whether held locally, regionally, nationally and even internationally. The method used in this training are preparation, debriefing and continuity of activities. The implementation of activities was carried out online through the zoom application in the form of exposure to theoretical understanding for the next stages of sustainability activities in direct offline mentoring and training to teachers. The result of this training was that the
\end{abstract}


teachers have in-depth knowledge of English debate and recommendations for offline strengthening training for English teachers at the SMA/SMK level in West Seram Regency.

Key Words: Training of English Debate System, Teacher of Senior High School and Vocational High School (SMA/SMK)

\section{PENDAHULUAN}

Pembelajaran Bahasa Inggris dirasakan belum efektif dalam pelaksanaannya. Tujuan utama pembelajaran Bahasa Inggris yakni siswa mampu berkomunikasi lisan maupun tulisan dengan baik secara komunikatif. Dalam konteks Bahasa Inggris sebagai bahasa asing, intensitas penggunaan Bahasa Inggris secara aktif lisan maupun tulisan tidak digunakan sesering pada konteks penggunaan Bahasa Inggris sebagai bahasa kedua. Intensitas yang kurang inilah yang membuat kemampuan berbicara (speaking) siswa dinilai masih renah. Kegiatan pembelajaran kurang mendorong siswa untuk sering berkomunikasi dalam kelas dengan menggunakan Bahasa Inggris. Kendatipun proses pembelajaran Bahasa Inggris telah dimulai dari pendidikan sekolah tingkat dasar hingga perguruan tinggi namun berkomunikasi Bahasa Inggris secara fasih masih sulit dilakukan oleh para siswa bahkan guru. Di samping itu ada juga faktor intrinsik siswa, seperti kurang percaya diri dan masih merasa takut berbicara Bahasa Inggris dengan aturan kaidah bahasa yang kaku dan tidak aplikatif.

Ketrampilan berbicara menjadi salah satu ketrampilan yang penting selain menyimak, membaca, dan menulis. Berbicara merupakan sarana komunikasi yang alami antara anggota masyarakat untuk mengekspresikan pikiran dan sebagai bentuk perilaku sosial. Seorang pembicara (speaker) harus mengembangkan metode atau teknik untuk persiapan dan menyusun percakapan, serta menganggap dan menanggapi orang lain. Hal ini senada dengan pernyataan Huda bahwa pembicara harus mengembangkan teknik untuk persiapan, untuk menyusun percakapan, untuk memberikan energi dan semangat, serta untuk menangkap dan menanggapi selera mereka (Huda, 1999). Dasar dari percakapan yang efektif adalah persiapan yang kompeten (Nadi Ali \& Fatimah, 2016).

Konteks pembelajaran di masa pandemik ini membutuhkan metode pembelajaran yang dapat mengembangkan kemampuan komunikasif siswa untuk menyampaikan ide atau pendapat secara bebas terarah melalui argumentasi dengan metode sistem debat. Sistem debat menstimulasi siswa untuk berkomunikasi interaktif secara spontan, adaptif dan kritis analitik. Metode debat merupakan salah satu metode yang cukup efektif dalam mengembangkan kemampuan komunikasi Bahasa Inggris secara fasih dan berpikir kritis berdasarkan fakta, bukti dan argumentasi yang kuat.

Debat Bahasa Inggris dalam pembelajaran bahasa merupakan salah satu strategi yang digunakan untuk meningkatkan keahlian berbicara dalam Bahasa Inggris. Aktifitas ini sangat berkaitan erat dengan bentuk diskusi yang lebih mendalam dan luas pada wilayah argumentasi antara pro dan kontra. Debat merupakan salah satu prosedur parlemen yang dirancang untuk memberikan dukungan maupun bantahan atas suatu permasalahan sebagai satu peluang yang memberikan bukti dan argumen atas kesimpulan sebelum para pengambil kebijakan memberikan keputusannya (Ewbank and Auer, 1947). Selain itu debat juga dapat mengembangkan beberapa aspek pengembangan siswa untuk melatih kemampuan mental dan psikis, meningkatkan kemampuan berpikir, mengungkapkan pemikiran dan menjadi 
pendengar yang efektif, membantu siswa dalam kehidupan sosial di tingkat global, dan meningkatkan karakter etika siswa (Balcer and Seabury, 1965).

Pelatihan sistem debat Bahasa Inggris bertujuan untuk meningkatkan kesadaran dan kemampuan guru dalam rangka melakukan pendampingan bagi siswa pada ajang kompetisi debat bahasa Inggris, baik di tingkat lokal, regional, nasional hingga internasional. Beberapa sistem yang digunakan dalam metode debat tingkat SMA/SMK yakni World School Debate System, Asian Parliamentary System maupun Australasian Parliamentary System. Kegiatan pelatihan ini dapat menghasilkan guru yang profesional dan kompeten dalam berkomunikasi Bahasa Inggris dengan melibatkan cara berpikir kritis. Berpikir kritis mengandung arti optimalisasi informasi yang logis sebagai dasar pemikiran. Informasi yang logis dan sesuai untuk dapat mendukung analisis dan pengambilan keputusan dalam proses berpikir kritis didapatkan melalui literasi (Patterson, 2011).

Permasalahan yang dihadapi dalam pembelajaran Bahasa Inggris diantaranya belum adanya kegiatan ekstrakurikuler dimana guru dapat melatih kemampuan siswa dalam debat Bahasa Inggris karena kurangnya peminatnya. Selain itu, ada juga faktor minimnya sumber daya manusia yang mampu memberikan pelatihan debat dalam Bahasa Inggris dan pelatihan sistem debat yang sering dilakukan secara insidental untuk mengikuti lomba sehingga tidak dapat dirasakan manfaatnya oleh guru.

Tujuan dari penyelenggaraan sistem debat Bahasa Inggris bagi para guru SMA/SMK adalah untuk meningkatkan kesadaran dan kemampuan guru dalam rangka melakukan pendampingan pada kegiatan debat di tingkat kabupaten kota, provinsi, regional, nasional dan internasional serta mengimplementasikan sistem debat dalam proses komunikasi global dengan Bahasa Inggris di dalam lingkungan kelas maupun luar kelas. Demikian juga untuk mendesain pembelajaran Bahasa Inggris yang efektif khususnya dalam meningkatkan kemampuan berbicara siswa di kelas dan melatih kemampuan berBahasa Inggris baik secara kaidah bahasa maupun sistem debat yang ada. Manfaat dari penyelenggaraan pelatihan sistem debat Bahasa Inggris bagi para guru SMA/SMK adalah untuk membentuk kepribadian siswa yang mampu berkompetisi dalam berbagai kegiatan kompetisi debat Bahasa Inggris di tingkat lokal, regional, nasional, hingga internasional.

\section{METODE}

Metode pelaksanaan kegiatan pelatihan sistem debat Bahasa Inggris ini meliputi beberapa tahapan kegiatan. Tahapan persiapan dan pembekalan diawali dengan tahap obervasi awal pada minggu ketiga bulan Maret. Dilanjutkan pada minggu pertama bulan April dengan mengidentifikasi masalah dan kebutuhan yang ditemui. Di minggu terakhir bulan April dilakukan penyusunan proposal. Setelah disetujui, dilakukan pengurusan surat ujin kegiatan pengabdian masyarakat pada minggu ketiga bulan Mei 2021. Tahapan selanjutnya yakni pelaksanaan kegiatan yang berlangsung pada tanggal 2 September 2021 pada pukul 13.00-16.00 WIT yang dilaksanakan secara daring melalui aplikasi Zoom. Kegiatan ini difokuskan pada pemaparan materi secara komprehensif dengan metode ceramah, diskusi dan tanya jawab. Tahapan akhir yakni rencana kerberlanjutan program dengan melaksanakan dan mengembangkan asosiasi debat Bahasa Inggris pada level SMA/SMK se-Kabupaten Seram Bagian Barat. Luaran dari pelatihan ini yakni menghasilkan kualitas sumber daya guru dan siswa yang memiliki pemahaman yang 
mendalam mengenai sistem debat tingkat SMA/SMK dan kemampuan berkomunikasi Bahasa Inggris secara kritis, analitik dan profesional melalui pendampingan, pelatihan dan media asosiasi yang dipersiapkan ke depan sebagai tindak lanjut pelatihan ini.

\section{HASIL DAN PEMBAHASAN}

Pelaksanaan kegiatan pengabdian dilakukan menggunakan cara mensosialisasikan materi menggunakan media Powerpoint. Kegiatan yang dilaksanakan secara daring berjalan dengan baik dan lancar. Proses pelatihan dengan metode ceramah dilanjutkan dengan tanya jawab dan diskusi tentang konsep dan pengalaman para guru Bahasa Inggris tentang sistem debat yang digunakan di tingkat sekolah menengah atas. Kegiatan ini dilaksanakan sehari yakni pada hari kamis, tanggal 02 September 2021 dari pukul 13.00 - 16.00 WIT. Peserta kegiatan berjumlah 65 orang yakni para guru Bahasa Inggris SMA/SMK se-Kabupaten Seram Bagian Barat (SBB). Pada tahap ini narasumber menjelaskan kepada para guru mengenai pentingnya debat yang berkaitan erat dengan kemampuan keahlian abad 21. Jika dilihat dari lokasi dan penerapannya di sekolah, debat dioptimalkan oleh para guru di sekolah untuk menghadirkan lingkungan belajar yang kondusif, edukatif, interaktif, agar tidak monoton dan membosankan bagi para siswa. Dengan metode pembelajaran ini, siswa dimotivasi dan didorong untuk aktif berbicara dan menguasai materi serta cakap mempresentasikan argumentasi pikirannya di depan publik. Ketrampilan ini mulai diterapkan oleh guru untuk membuat para siswa di sekolah menjadi pembelajar yang berani untuk mengutarakan pendapatnya. Aktifitas ini sangat mendukung mental dan kepercayaan diri siswa untuk cerdas berprestasi tidak saja pada ajang kompetisi namun memenangkan perhatian publik atas argumentasi yang cermat, kritis serta berorientasi pada solusi atas suatu permasalahan. Sehingga kegiatan debat menjadikan proses pembelajaran komunikasi Bahasa Inggris menjadi lebih dinamik, interaktif sekaligus kritis dan analitis, dan tentunya jauh lebih menyenangkan. Kegiatan pelatihan sistem debat dapat dilihat pada gambar 5.3 dibawah ini.
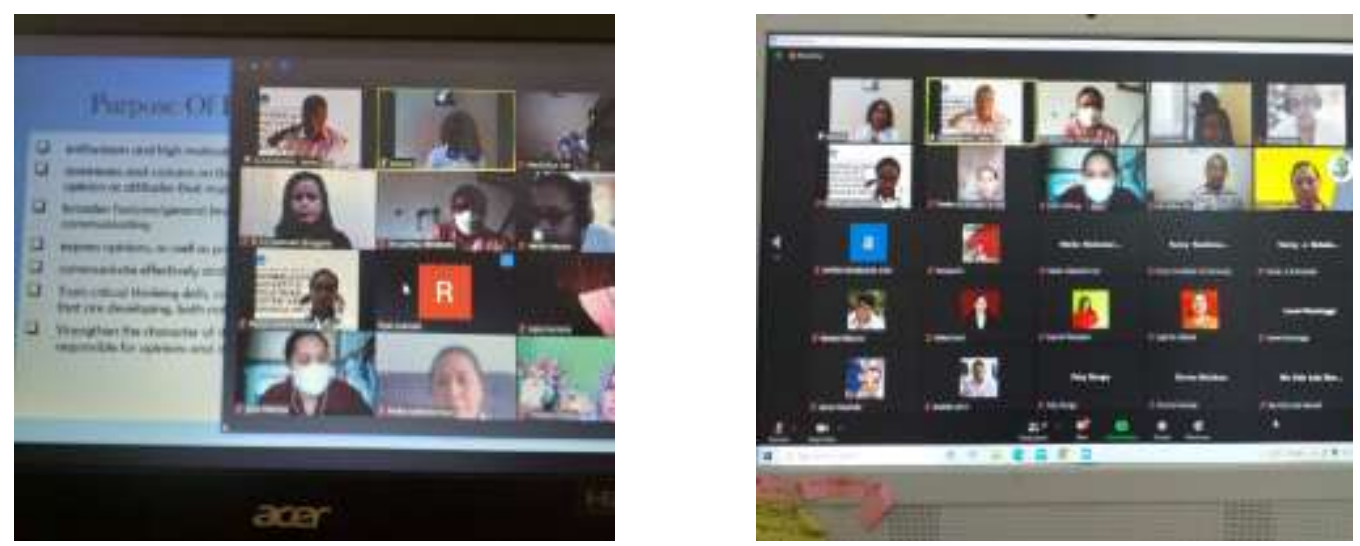

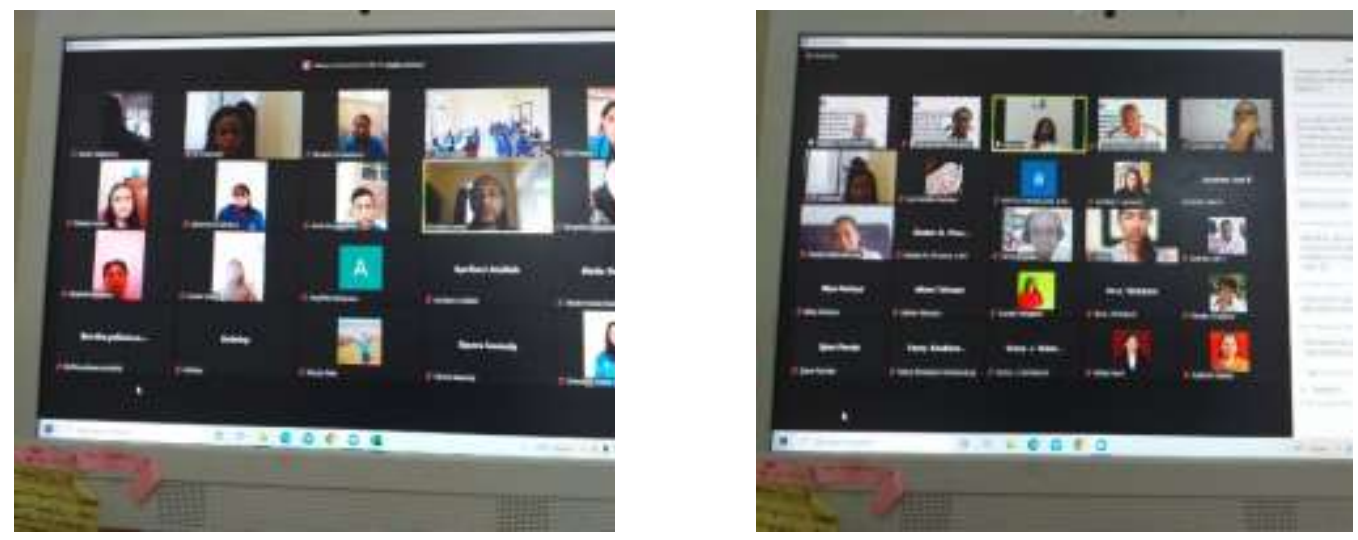

Gambar 5.3. Dokumentasi Kegiatan Pelatihan Debat

Pelaksanaan kegiatan Program Pembelajaran dan Pemberdayaan Masyarakat (PPM) dilaksanakan secara daring kepada para guru Bahasa Inggris di Kabupaten Seram Bagian barat (SBB). Kegiatan ini diawali dengan tahap persiapan. Pada tahap ini, penyusunan jadwal kegiatan, penyusunan materi debat Bahasa Inggris, dan koordinasi dengan mitra yang terlibat dalam MGMP Bahasa Inggris tingkat SMA/SMK di Kabupaten Seram Bagian Barat. Selanjutnya tahap pelaksanaan berupa sosialisasi sistem debat pada ajang kompetisi tingkat nasional dan internasional bagi para guru Bahasa Inggris tingkat SMA/SMK di Kabupaten Seram Bagian Barat. Pada kegiatan ini, proses sosialsiasi ini berlangsung dengan sangat baik, lancar, efisien dan efektif. Hal ini sangat terbukti dengan interaksi yang dibangun selama proses pelatihan secara daring. Antusias dan pemahaman para guru tampak lebih baik terkait debat Bahasa Inggris.

Pada pelaksanaan kegiatan Program Pembelajaran dan Pemberdayaan Masyarakat (PPM) dengan judul "Pelatihan Sistem Debat Bahasa Inggris bagi Guru-Guru Bahasa Inggris se-Kabupaten Seram Bagian Barat" dihasilkan Panduan Debat Bahasa Inggris tingkat sekolah. Panduan merupakan bahan ajar yang disusun secara sistematis yang berisi tentang format debat, peran pembicara, dan tata cara berdebat dalam Bahasa Inggris. Materi dalam panduan ini disesuaikan dengan kebutuhan para guru di sekolah untuk memberikan pendampingan kepada siswa dalam perlombaan debat tingkat lokal, regional, nasional dan internasional.

Kegiatan sosialisasi ini berlangsung dengan menggunakan panduan sebagai media pembelajaran, di samping materi disajikan dalam bentuk presentasi dan tampilan power point. Penggunaan panduan ini bertujuan agar peserta pelatihan dapat belajar secara mandiri tanpa atau dengan dibimbing oleh pengajar (tutor). Selain itu, penggunaan panduan debat tersebut dalam kegiatan ini memberikan inspirasi bagi para peserta yang dalam hal ini para guru agar lebih kreatif dalam merancang proses pembelajaran yang lebih interaktif sehingga motivasi siswa untuk komunikasi aktif Bahasa Inggris lebih meningkat.

Debat dapat dijadikan sebagai metode dalam proses pembelajaran. Metode debat merupakan metode metode pembelajaran yang efektif untuk mengasah argumentasi siswa dalam kelompok maupun individu dengan berorientasi pada pemecahan masalah atau memberikan solusi terhadap permasalahan yang dihadapi. Metode debat merupakan metode yang membantu para peserta didik menyalurkan ide, gagasan dan pendapatnya. Kelebihan metode ini yakni pada daya membangkitkan keberanian mental peserta didik dalam berbicara Bahasa Inggris dan bertanggungjawab atas pengetahuan yang didapat melalui proses debat, 
baik di kelas maupun di luar kelas. Adapun tahapan dari metode debat di dalam pelatihan ini yakni:

a) Menentukan topik permasalahan yang aktual dan kontroversial yang menjadi isu publik.

b) Membagi siswa di dalam kelas atas tiga kelompok. Masing-masing kelompok pro dan kontra,

c) Menentukan alokasi waktu untuk masing-masing kelompok pembicara dari kelompok pro dan kontra.

d) Tim pro maksimal 3 orang.

e) Tim kontra maksimal 3 orang,

f) Tim Juri yang terdiri dari 1 ketua tim juri dan minimal 2 orang panelis

Debat merupakan forum yang sangat tepat dan strategis untuk mengembangkan kemampuan berpikir dan mengasah ketrampilan berbicara yang komunikatif dan interaktif. Debat juga dapat memberikan kontribusi yang bermanfaat dan berfaedah bagi kehidupan sosial masyarakat bahkan masyarakat global.

\section{KESIMPULAN}

Kegiatan pengabdian ini bertujuan membekali dan melatih pengembangan kemampuan berpikir kritis melalui ketrampilan berbicara Bahasa Inggris bagi para guru Bahasa Inggris untuk tingkat SMA/SMK di Kabupaten Seram Bagian Barat (SBB). Pelatihan ini dilakukan dengan pendekatan teknik debat Bahasa Inggris karena dalam debat berpikir kritis menjadi fondasi utama dalam penyampaian pendapat. Dengan adanya pelatihan bagi para guru, pelakasana pengabdian berharap para guru dapat melatih siswa untuk mengembangkan kemampuan berpikir kritis di sekolah. Kegiatan pelatihan sistem debat Bahasa Inggris untuk para guru SMA/SMK se-Kabupaten Seram Bagian Barat (SBB) berjalan dengan lancar dan berhasil mencapai target yang diharapkan dalam pelatihan ini. Antusiasme para guru dalam respon positif selama kegiatan pelatihan ini memberikan gambaran capaian pemahaman yang efektif dan efisien bagi para guru terkait sistem debat Bahasa Inggris untuk menjadi salah satu metode pembelajaran efektif yang dapat dioptimalkan di sekolah. Untuk mengisi kekurangan keterbatasan waktu pelatihan, maka rekomendasi kegiatan lanjutan melalui pelatihan secara luring lanjutan bahkan pendirian asosiasi debat Bahasa Inggris untuk tingkat SMA/SMK.

\section{REFERENSI}

Balcer, C.L. \& Seabury, H.F. 1965. Teaching Speech in Today's Secondary Schools. New York: Holt, Rinehart \& Winston, Inc.

Ewbank, H.L. \& Auer, J.J. 1947. Discussion \& Debate: Tools of a Democracy. New York: F.S.Crofts \& Co.Inc.

Huda, M. 1999. Cooperative Learning. Yogyakarta: Pustaka Belajar.

Nadi, Ali \& Fatimah. 2016. Developing EFL Learner's Speaking Ability, Accuracy \& Fluency, English Language and Literature Studies, Volume 6, Number 2.

Patterson, F. 2011. Visualizing the Critical Thinking Process. Issues, 36-41 